\title{
THE FINANCIAL FEASIBILITY OF DELAYING SOCIAL SECURITY: EVIDENCE FROM ADMINISTRATIVE TAX DATA
}

\author{
Gopi Shah Goda \\ Shanthi Ramnath \\ John B. Shoven \\ Sita Nataraj Slavov \\ Working Paper 21544 \\ http://www.nber.org/papers/w21544
NATIONAL BUREAU OF ECONOMIC RESEARCH 1050 Massachusetts Avenue
Cambridge, MA 02138
September 2015

The findings and conclusions expressed are solely those of the author(s) and do not represent the views of the U.S. Department of the Treasury, or the NBER. We thank seminar participants at George Mason University's School of Policy, Government, and International Affairs and the Tax Economists Forum for helpful comments.

NBER working papers are circulated for discussion and comment purposes. They have not been peerreviewed or been subject to the review by the NBER Board of Directors that accompanies official NBER publications.

(C) 2015 by Gopi Shah Goda, Shanthi Ramnath, John B. Shoven, and Sita Nataraj Slavov. All rights reserved. Short sections of text, not to exceed two paragraphs, may be quoted without explicit permission provided that full credit, including (C) notice, is given to the source. 
The Financial Feasibility of Delaying Social Security: Evidence from Administrative Tax

Data

Gopi Shah Goda, Shanthi Ramnath, John B. Shoven, and Sita Nataraj Slavov

NBER Working Paper No. 21544

September 2015

JEL No. D14,H31,H55

\section{ABSTRACT}

Despite the large and growing returns to deferring Social Security benefits, most individuals claim Social Security before the full retirement age, currently age 66. In this paper, we use a panel of administrative tax data on likely primary earners to explore some potential hypotheses of why individuals fail to delay claiming Social Security, including liquidity constraints and private information regarding one's expected future lifetime. We find that approximately $31-34 \%$ of beneficiaries who claim prior to the full retirement age have assets in Individual Retirement Accounts (IRAs) that would fund at least 2 additional years of Social Security benefits, and 24-26\% could fund at least 4 years of Social Security deferral with IRA assets alone. Our analysis suggests that these percentages would be considerably higher if other assets were taken into account. We find evidence that those who claim prior to the full retirement age have higher subjective and actual mortality rates than those who claim later, suggesting that private information about expected future lifetimes may influence claiming behavior.

\author{
Gopi Shah Goda \\ Stanford University \\ SIEPR \\ 366 Galvez St. \\ Stanford, CA 94305 \\ and NBER \\ gopi@stanford.edu \\ Shanthi Ramnath \\ Department of the Treasury \\ Shanthi.Ramnath@do.treas.gov
}

\author{
John B. Shoven \\ Department of Economics \\ 579 Serra Mall at Galvez Street \\ Stanford, CA 94305-6015 \\ and NBER \\ shoven@stanford.edu \\ Sita Nataraj Slavov \\ School of Policy, Government and \\ International Affairs \\ George Mason University \\ 3351 Fairfax Drive \\ Arlington, VA 22201 \\ and NBER \\ sslavov@gmu.edu
}




\section{Introduction}

An important decision that most Americans face near retirement is when to claim Social Security benefits. While benefits can be claimed as early as 62 , individuals who delay claiming receive higher annual benefits to compensate for the reduction in the expected number of years over which benefits will be paid. A growing body of literature has documented the large and increasing returns to delaying the onset of Social Security benefits, particularly for primary earners (e.g., Sun and Webb 2009; Sass et al. 2013; Shoven and Slavov 2014a,b). The advantage of delaying has grown considerably over the last several decades due to changes in Social Security rules (including increases in the credit for delaying Social Security beyond full retirement age), changes in real interest rates, and changes in life expectancy, and there is advantage to delaying even for individuals with mortality rates twice the average rate in the population (Shoven and Slavov 2014a,b).

However, despite the fact that a large proportion of the population can gain financially by delaying their Social Security benefit, the majority of beneficiaries claim benefits before the full retirement age (66 for individuals born between 1943 and 1954), and very few delay to age 70 (see SSA 2013, Table 6.A4). ${ }^{1}$ There are several hypotheses that may explain why individuals claim Social Security earlier than the age that maximizes the expected monetary value of benefits. Individuals may believe that, due to Social Security's long-term financial shortfall, their Social Security benefits could be reduced if not claimed as soon as possible. Individuals may view the full retirement age as a reference point or recommendation by the government (Behaghel and Blau 2012), choosing to claim at that age even though it may increase wealth to

\footnotetext{
${ }^{1}$ The fraction of individuals claiming Social Security at the earliest age possible, age 62, has slowly been declining over time, but it is still large. According to Munnell and Chen (2015), 51.9 percent of men and 63.6 percent of women in the 1923 birth cohort claimed at 62, compared with 35.6 percent of men and 39.5 percent of men in the 1951 birth cohort.
} 
wait until age 70. Many individuals may choose to claim at the same time they retire from a career job, which may be out of their control due to unexpected job loss or disability, or may be driven by health insurance availability via Medicare. Alternatively, individuals tend to undervalue annuities and may therefore not value the marginal increase in their Social Security annuity from deferring (Fitzpatrick forthcoming; Chai et al. 2013). In this paper, we focus on two leading explanations. The first is that individuals who wish to stop working before their wealthmaximizing claiming age may be liquidity constrained and lack the ability to borrow against assets to finance a delay. The second is that individuals who claim early do so because they face higher mortality rates. The latter explanation could operate through different channels. For example, higher mortality directly reduces the gains from delaying Social Security, potentially making early claiming optimal. Also, those with higher mortality rates are likely to stop working earlier, and individuals may believe that the appropriate time to claim is upon stopping work. Prior studies have shown a correlation between early claiming and subjective mortality (Hurd, Smith, and Zissimopoulos 2004; Glickman and Hermes 2015) as well as actual mortality (Beauchamp and Wagner 2012; Waldron 2002).

We assemble a panel of administrative tax data for the 1940 birth cohort. Our panel includes annual data for 1999 through 2011, allowing us to observe individuals from ages 59 through 71. Our sample restrictions drop individuals who died before 1999, individuals who received disability benefits or other Social Security benefits before age 62, and women who were married and filing a joint return for some year between 1999 and 2011. These sample restrictions allow us to focus on those who are more likely to be primary earners making decisions about when to claim Social Security. 
Using information returns we are able to observe the year of Social Security claiming, the pattern of distributions from tax-deferred retirement accounts, and the fair market value of Individual Retirement Account (IRA) assets. We have several findings. First, we show that the vast majority of our sample claims Social Security before the full retirement age, with more than a third claiming Social Security at the earliest eligible age of 62 . Second, $56.6 \%$ of our sample takes distributions from their IRA after they claim Social Security, with an average time between Social Security claiming and first IRA distribution of 1.6 years. We then construct the ratio of IRA fair market value at the time an individual claims Social Security to their annual Social Security benefit, and show that approximately $31-34 \%$ of beneficiaries who claim before the full retirement age have IRA assets to finance at least 2 years of Social Security benefits and that 24$26 \%$ of beneficiaries have IRA assets to finance at least 4 years of Social Security benefits. These results suggest that liquidity constraints are not likely to be the main reason a significant segment of the population chooses to claim early since IRA assets can be tapped into without any penalty at these ages and do not represent the only sources of wealth for many of these individuals.

We also examine the hypothesis that expectations about one's future mortality influences claiming decisions, either directly by lowering the gains from delay or indirectly through work decisions, by analyzing the relationship between Social Security claim age and observed mortality. Because the returns to delaying are lower for people with higher mortality, and because people with higher mortality are likely to stop working earlier, we would expect that individuals who believe they have higher than average mortality claim earlier than those who believe they have lower than average mortality. Our results support this conclusion: individuals who claim before the year they turn age 65 have an $80 \%$ higher mortality hazard of dying 
between the year they turn 66 and the year they turn 71 than those who claim after the year they turn age 65 . These differences persist across subsamples with different levels of wealth.

Finally, we supplement our analysis of administrative tax data by examining a similar sample from the Health and Retirement Study (HRS). While the HRS has a considerably smaller sample size relative to our administrative data, it has the advantage of including a much richer set of variables. We investigate how other characteristics vary between those who claim before the full retirement age and those who claim after the full retirement age after controlling for wealth, age, cohort, race, education, and gender. We find that those who claim prior to the full retirement age are less likely to report being in good or excellent health and have a significantly lower subjective probability of living to age 75 , reinforcing the idea that mortality expectations influence claiming decisions.

Our main contribution to the literature comes from our use of administrative tax data from the Internal Revenue Service (IRS), an extremely large and rich dataset that allows us to analyze the full 1940 birth cohort, conditional on survival to age 59. Prior studies of claiming behavior have typically focused on household survey data from the Health and Retirement Study (HRS). A key advantage of the IRS administrative data, other than sample size, is that it provides detailed information on withdrawals from retirement accounts, which are generally not recorded in household surveys like the HRS. While some prior studies have examined the relationship between claiming age and the stock of wealth (e.g., Hurd et al. 2004; Glickman and Hermes 2015), to our knowledge we are the first to examine the relationship between claiming age and wealth drawdown behavior. Our dataset is also ideal for analyzing the mortality experience of early versus late claimers. Our mortality findings corroborate and update the results of Beauchamp and Wagner (2012), who examine actual mortality in a smaller sample from the 
HRS, and Waldron (2002), who examines mortality using administrative Social Security data and focuses on earlier birth cohorts who faced smaller gains from delaying Social Security. The main disadvantage of our administrative data is that it contains very little demographic or personal information that does not appear on tax returns. Thus, we complement our analysis with results from the HRS, which contains a rich set of covariates and information on several types of wealth.

We use these data sources to document several stylized facts. First, a significant portion of the sample has the ability to defer Social Security benefits at each claiming age by using the wealth in their IRAs, a lower bound of the total wealth available. Second, Social Security benefits are generally claimed earlier than IRA withdrawals are made. Finally, both subjective expectations of future mortality (from the HRS data) and actual realized mortality (from the IRS data) differ for those who claim benefits before the full retirement age relative to those who claim after the full retirement age. We note that this finding could be driven by earlier exits from the labor force among those with work-limiting disabilities and the close link between decisions to retire and claim Social Security benefits.

The remainder of this paper proceeds as follows. In Section II, we describe the sample selection in both the administrative tax data and the HRS. We analyze the distribution of Social Security claim ages and the timing of IRA withdrawals in Section III, and also report IRA wealth held by members of our sample at different claim ages. In Section IV, we discuss other associations with Social Security claiming ages, and Section V concludes.

\section{Data}

a. Tax Return Data 
Our data come from the population of tax and information returns collected by the Internal Revenue Service (IRS). We use supplementary information provided by the Social Security Administration (SSA) on date of birth, gender, and date of death to restrict our sample to individuals who were born in 1940. We then construct a panel spanning 1999 to 2011; thus, we observe the 1940 cohort from ages 59 through 71 . Our dataset contains information on household income (Form 1040), wage earnings and employee contributions to employer-sponsored retirement plans (Form W2), distributions from IRAs and distributions from employer-sponsored retirement plans (Form 1099R), contributions to and account balances of IRAs (Form 5498), and Social Security payments (Form 1099-SSA). The initial 1940 birth cohort has 2,617,194 individuals, comprising both filers and nonfilers. ${ }^{2}$ Because the data are unedited, we make a number of restrictions in an effort to remove observations with erroneous information. We drop individuals who died before 1999 or who do not receive a 1040, W-2, or 1099-SSA over the entire sample period. We also drop same sex couples, individuals with unidentified gender, and individuals who do not have Social Security numbers. These restrictions reduce the sample to $2,339,893$.

We define an individual's year of claiming Social Security as the first year in which the individual received a 1099-SSA reporting Social Security payments. All types of Social Security payments, including retired worker benefits, auxiliary (spousal or survivor) benefits, disability benefits, and railroad benefits are included on the 1099-SSA. The gains from delaying Social Security are substantial for retired worker benefits. However, they are much more modest for spousal and survivor benefits, which do not grow with delay beyond the full retirement age. In addition, railroad benefit recipients face different rules for benefit computation, and disability

\footnotetext{
${ }^{2}$ Because nonfilers do not file Form 1040 or its counterparts, we lack some information on these individuals, including their marital status.
} 
recipients are automatically switched to retirement benefits at the full retirement age and thus face a very different claiming decision. Ideally, therefore, we would like to exclude individuals who receive anything other than retired worker benefits. The 1099-SSA reports whether an individual's benefit is drawn from the disability or railroad trust fund. We use this information to drop all individuals who received a these benefits at any point during the sample period. ${ }^{3}$ Unfortunately, the form does not report whether a non-disabled individual's benefit is a worker, survivor, or spousal benefit. As an alternative, we attempt to eliminate individuals who have a high probability of claiming spousal and survivor benefits. Since these auxiliary benefits are claimed primarily by married women, we retain only the male member of married couples, as well as singles of any gender. ${ }^{4} \mathrm{We}$ also eliminate individuals whose benefit is drawn from the retirement trust fund, but who claimed before 2002 (age 62). These individuals are likely to be receiving survivor benefits, which can be claimed as early as age 60 . These restrictions reduce our sample to $1,238,927$ observations. Even after this sample selection, it is still possible that some of our singles are receiving survivor benefits or spousal benefits based on an ex-spouse's record. However, there is no way to identify these individuals in the data. Of the remaining 1,238,927 observations, 91 percent claim Social Security at some point between 1999 and 2011. We drop individuals who never claim Social Security, leaving a sample of $1,127,977$, consisting of roughly $24 \%$ single men, $54 \%$ married men, and $22 \%$ single women.

Our information on wealth comes from Form 5498, which reports the fair market value of IRAs. Unfortunately, tax records do not contain information on other kinds of wealth, including defined contribution balances. IRA balances therefore provide a lower bound on the wealth that

\footnotetext{
${ }^{3}$ The disability trust fund indicator is missing for 1.23 percent of records in 2004. We assume that these individuals received retirement benefits in 2004.

${ }^{4}$ In this step, nonfilers are assumed to be single, as we do not have information about their marital status. Single men and women also include those who were previously married and are now widowed or divorced.
} 
can be used to delay Social Security. To compare Social Security claiming behavior with retirement account claiming behavior, we use information from Form 1099-R, which reports distributions from IRAs and employer sponsored pension plans. Distributions from employersponsored pension plans include payments from both defined benefit and defined contribution plans. Since defined benefit plans do not represent a source of liquid wealth that can be used to delay Social Security, and since individuals have less flexibility regarding the timing of defined benefit distributions, we would ideally like to focus only on distributions from IRAs and defined contribution plans. While IRA distributions are identified separately on the 1099-R, defined benefit and defined contribution distributions are not distinguishable. Therefore, we once again focus only on IRAs. ${ }^{5}$ Among the sample of 1,127,977 individuals who claim Social Security at some point during the sample period, 40 percent take distributions from both IRA and employer plans, 12 percent take distributions from IRAs only, and 27 percent take distributions from employer plans only.

In addition to comparing the timing of IRA distributions and Social Security claiming ages, we also examine the ratio of IRA wealth at the time of Social Security claiming to the average Social Security benefit for one's gender and claiming age in the 1940 birth cohort. While the tax data includes data on Social Security income, as discussed above, it does not distinguish between different types of benefits (i.e., spousal, retirement, etc.). It also does not indicate if an individual's benefit has been reduced due to the earnings test. We therefore use the Social Security Benefits and Earnings Public Use File, a dataset containing administrative Social Security data on a random sample of individuals receiving benefits in December 2004, to calculate the average retired worker's primary insurance amount (PIA) by gender. These PIAs

\footnotetext{
${ }^{5}$ In an attempt to exclude rollovers, which are also reported on 1099-R, we keep only distributions with codes 7,B,D,F,L,Q,and T.
} 
are inflated or deflated to the year in which wealth is measured using the Social Security cost-ofliving adjustment. Of course, an individual receives his or her PIA only if benefits are claimed at the full retirement age. To determine the average benefit that would be available at the individual's claiming age, we adjust these PIAs using the actuarial reduction factors for claims made before the full retirement age, and delayed retirement credits for claims made after the full retirement age. ${ }^{6}$ We then examine the ratio of IRA wealth to the average Social Security benefit based on the individual's gender. This ratio indicates how much longer an individual could potentially have delayed Social Security, using IRA wealth alone, at the time of their claim. ${ }^{7}$ Because we only observe IRA wealth, and not total wealth, this estimate of the additional delay that could be financed can be viewed as a lower bound. As we will explain in the following section, we can use the Health and Retirement Study, which contains information on total wealth, to approximate how tight that lower bound is.

\section{b. HRS data}

The Health and Retirement Study (HRS) is a biennial panel survey intended to be representative of the population aged 50 and older. The survey began in 1992, with new cohorts added periodically to keep the sample representative of the target population. We begin with 38,130 individual-level observations from the RAND version of the HRS from the 11 waves of the survey available at the time of analysis, collected between 1992 and 2012. The HRS includes information on Social Security income. However, it does not distinguish among the different types of benefits. Thus, we drop anyone who claimed benefits before age 62 , as well as anyone

\footnotetext{
${ }^{6}$ Because we identify the age of Social Security claiming from the year in which the 1099-SSA is received, we do not know the exact month of claiming in our IRS sample. Therefore, we assume that benefits are claimed at half birthdays and apply the appropriate reduction factors and delayed retirement credits based on claiming at 62.5 for 2002, 63.5 for 2003, etc.

${ }^{7}$ Since withdrawals from traditional IRAs are taxable, while Social Security benefits for most people are not, ideally we would use post-tax IRA wealth in this calculation. While we do observe each individual's current tax bracket, withdrawing money from an IRA is likely to change that tax bracket. Thus, we do not have a good way to estimate after-tax IRA wealth. This means that our ratios are likely to overstate the amount of deferral possible.
} 
who reports receiving either Social Security disability benefits or Supplemental Security Income due to disability. These eliminations reduce the sample size to 31,999 . Next, we drop individuals with missing Social Security claim dates and missing birth years, as well as individuals who are not observed all the way through their full retirement age (as we cannot determine if these individuals delayed until the full retirement age). These restrictions reduce the sample size to 10,710. If individuals were surveyed at age 62 , we look at their wealth and most other characteristics from that wave. For individuals who were not surveyed at age 62 , we look at their characteristics from the wave in which they were either 61 or 63 . Individuals who were not observed at any of these ages are dropped, reducing the sample to 7,125. We also drop married women $^{8}$, individuals with less than 10 years of work history (who are unlikely to qualify for Social Security), and individuals with missing education or race. Our final sample contains 4,362 observations, of which roughly 67 percent are married men, 12 percent are single men, and 21 percent are single women. ${ }^{9}$ The individuals in this sample were born between 1928 and 1947.

The RAND HRS includes information on household-level IRA wealth, as well as total non-retirement financial wealth. Total non-retirement financial wealth includes checking and savings accounts, certificates of deposit, bonds, stocks, mutual funds, and any other savings less debt. To obtain the value of defined contribution balances, we merge in a supplemental dataset, created by Gustman, Steinmeier, and Tabatabai (2014), containing estimates of pension wealth through the 2010 wave. We aggregate defined contribution balances by household, using the HRS tracker file to identify couples. These household-level defined contribution balances are added to the existing RAND measures of household-level IRA and non-retirement wealth to

\footnotetext{
${ }^{8}$ Our definition of married does not include domestic partnerships as this definition is most consistent with the tax data, and domestic partners are not eligible for spousal or survivor benefits.

${ }^{9}$ The HRS data contain more married men and fewer single men compared to the tax data. We suspect this is because nonfilers are assumed to be single in the tax data.
} 
create total household wealth. ${ }^{10}$ Wealth is measured in the wave in which the respondent turns 62 (or, if not observed at 62, then 61 or 63).

Since our goal is to determine which individuals have sufficient wealth to delay Social Security, we need to compare wealth with the Social Security benefits that would be forgone during the delay period. We match individuals to the average PIA for their gender and birth cohort, calculated from the Social Security Earnings and Benefit Public Use File as described in the previous section. Since the benefit data does not include benefit information for workers who were born after 1942 (as these individuals would not have turned 62 by 2004), we inflate the average PIAs for the 1942 cohort by the average wage index and assign these to younger cohorts. To determine the average benefit that would be available at the individual's claiming age, we adjust these PIAs using the actuarial reduction factors for claims made before the full retirement age, and delayed retirement credits for claims made after the full retirement age. ${ }^{11}$ We then examine the ratio of both IRA wealth (for comparison with the tax data) and total wealth to the average benefit within the individual's gender and birth cohort. ${ }^{12}$ Before calculating these ratios, we inflate or deflate PIAs to the year in which wealth is measured using the Social Security costof-living adjustments. We then regress different characteristics on the quartile of one's wealth to Social Security benefit ratio, an indicator of whether the person claims Social Security prior to his or her full retirement age, and education, race, female, and marital status ${ }^{13}$ binary variables.

\footnotetext{
${ }^{10}$ The RAND HRS definition of a household includes both married couples and unmarried partners. Our wealth figures are based on this definition.

${ }^{11}$ For this calculation, individuals who are not observed to claim during the sample period (just under 4 percent of the sample) are assumed to claim at age 70. This assumption is conservative because it understates the ratio of wealth to benefits, thus providing a lower bound on the amount of delay that is feasible.

${ }^{12}$ Again, we would ideally like to use after-tax wealth in this calculation, but we do not have a good way to determine the tax rate on retirement account withdrawals that each person in the sample would face.

${ }^{13} \mathrm{~A}$ handful of individuals with missing marital status are coded as single. Again, our definition of married does not include domestic partnerships as domestic partners as this definition is most consistent with the tax data, and domestic partners are not eligible for spousal or survivor benefits.
} 
Since the returns to delaying Social Security differ for cohorts born prior to 1938, we also include a binary variable for whether one was born in 1938 or later. ${ }^{14}$

We examine a variety of different outcome variables to understand how those who claim prior to the full retirement age differ from those who claim at the full retirement age or later after controlling for wealth and other observable characteristics. These characteristics are measured in the wave in which the respondent turns 62 (or, if not observed at 62, then 61 or 63 ). Some of these characteristics are missing for some individuals in our sample, but each individual in our sample has a non-missing value for at least one of them. One set of outcome variables we analyze is own and spousal self-reported health status. Individuals are asked to rate their health as either poor, fair, good, very good, or excellent. We create an indicator that takes on a value of 1 if the individual reports a health status of good or better during the wave in which they are 62 . HRS respondents are also asked to estimate the chances that they will still be alive at age $75 .{ }^{15}$ Because this variable is missing for many individuals, we take the median of all the responses across waves. Comparing self-reported health status and subjective life expectancy helps us examine the hypothesis that mortality is an important factor in the decision to claim Social Security. ${ }^{16}$ Respondents also are asked to rate the probability of a cut in Social Security benefits - both in general and their own individual benefit - over the next 10 years. These variables are available for 2006 onwards, and we take the median of all available responses for each individual. We also explore whether those who claim prior to their full retirement age have

\footnotetext{
${ }^{14}$ Individuals who are never observed to claim during the sample period are assumed to have delayed to the full retirement age or later. An alternative explanation for this would be that these individuals are ineligible for Social Security. However, because the sample is restricted to those who have at least 10 years of work history, we would not expect this to apply to most individuals.

${ }^{15}$ In wave 1, respondents are asked to rate the chances of surviving to age 75 on a scale of $0-10$; these responses are multiplied by 10 to arrive at a probability of survival. In subsequent waves, respondents are asked to report the percent chance of living to 75 on a scale of $0-100$.

${ }^{16}$ The subjective survival probabilities reported in the HRS have been shown to be correlated with actual mortality (see, e.g., Hurd and McGarry 2002). Subjective survival probabilities are arguably more important than actual mortality in the decision to delay Social Security.
} 
different rates of long-term care insurance coverage, either for themselves or their spouse. Those without long-term care insurance may have more of a precautionary savings motive, leading them to preserve their wealth for potential long-term care spells. Finally, respondents are asked to rate their financial planning horizon on a scale of 1 (the next few months) to 5 (more than 10 years). This variable is available in 1992, and from 1998-2006. We take the median of the responses across all waves and create an indicator equal to 1 if the financial planning horizon variable is greater than or equal to 4 . We interpret this indicator as a proxy for the respondent's patience.

\section{Social Security Claim Ages, IRA Withdrawals and Liquidity Constraints}

Figure 1 shows the distribution of Social Security claiming ages and the first year of IRA distributions for individuals in our administrative tax sample. Consistent with previous research, more than a third of individuals claim in 2002 (at age 62). Another spike in claims occurs in 2005-06, as members of the 1940 cohort reach their full retirement age of $65 \frac{1}{2}$. Very few individuals delay their claims beyond this point. The middle panel shows the distribution of firsttime Traditional IRA withdrawals for the subset of individuals who have Traditional IRAs. ${ }^{17}$ Here, a very different pattern emerges. While there is a spike in withdrawals in 1999-2000 (as the cohort reaches age 591/2), it is far more common to wait until age 2010-11, when the cohort reaches age $70 \frac{1}{2}$ and required minimum withdrawals become mandatory. Finally, the bottom panel shows the distribution of first-time Roth IRA withdrawals for the subset of individuals with Roth IRAs. Here, since the basis of a Roth IRA can be withdrawn without penalty prior to age $59 \frac{1}{2}$, there is no observable spike in withdrawal activity in 1999 and 2000 . The majority of

\footnotetext{
${ }^{17}$ This sample is determined by an indicator of taking a distribution at some point during our sample period. Due to Required Minimum Distributions, most individuals with IRAs take distributions between the ages of 59 and 71.
} 
the sample withdraws from both Traditional and Roth IRAs in 2005 or later (57 and 71 percent, respectively), while the majority of Social Security claims occur prior to 2005 (59 percent).

Of course, the individuals depicted in the bottom panels of Figure 1 are a selected sample of those represented in the top panel of Figure 1. We therefore also compare the IRA and Social Security withdrawal behavior of the subset of individuals who have IRAs. Figure 2 provides a histogram of the difference between Social Security claiming age and Traditional IRA firstwithdrawal age for these individuals. Negative values indicate that Social Security was claimed first. Positive values indicate that the IRA first withdrawal occurred first. The figure shows that individuals with IRAs tend to claim Social Security before making IRA withdrawals, as most of the mass is on the left part of the graph. In particular, 57 percent of the sample claim Social Security benefits prior to withdrawing funds from IRAs. The spike at -5 represents individuals who claim Social Security at their full retirement age of $651 / 2$ and make their first withdrawal from their IRA at 701/2. Many individuals claim Social Security benefits in the same year they make their first IRA distribution. Only 33 percent of the sample claims Social Security benefits after they take distributions from their IRA. These IRA withdrawal results are consistent with the empirical finding that retired individuals draw down on their wealth much more slowly than the life cycle model would predict (see e.g., French and Jones 2010; Hurd 1990).

We next construct a measure of what proportion of the sample have IRA balances that could potentially allow someone to defer Social Security benefits. We take the sum of each individual's IRA fair market values (retrieved from Form 5498) and divide by the genderspecific average benefit received by the 1940 cohort at different ages. ${ }^{18}$ We then plot the percentage of our sample with IRA balances equal to at least twice the average benefit or at least four times the average benefit in Figure 3.

\footnotetext{
${ }^{18}$ We have performed this analysis using one's actual Social Security benefits and the results are extremely similar.
} 
The proportion with IRA wealth at least twice or four times the average benefit is on average 35 percent and 27 percent, respectively. In other words, approximately a third of the sample has an IRA balance that could allow them to defer Social Security benefits for an additional two years, while about one quarter have funds to defer for an additional four years. These numbers fluctuate over the study period, between a low of 25 percent ( 20 percent) in 2009 (2008) and a high of 42 percent (33 percent) in 2006 for two years (four years). There are two main reasons for these fluctuations. The first is market fluctuations that occurred between 2002 and 2010. The second is selection in claim ages. For instance, those who claim at age 62 may have different levels of wealth than those who claim at age 67. Still, the figure suggests that a significant share of our sample has funds that could allow them to delay claiming retirement benefits and in turn receive higher annual benefits due to the delayed retirement credit, even among those who claim prior to the full retirement age. These estimates are likely to be lower bounds since IRA wealth represents only part of total wealth that could potentially be used to delay Social Security.

\section{Other Characteristics that Influence Social Security Claiming Behavior}

We next examine alternative factors that may influence Social Security claiming behavior besides liquidity constraints. Due to the lack of information about people in our tax sample, we turn to our HRS sample to investigate how observable characteristics vary among those who claim prior to the full retirement age and those who claim after (or have attained their full retirement age but have not yet claimed).

Table 1 provides summary statistics for our sample, and Table 2 shows how early claiming behavior varies with wealth. According to Table 1, around 35 percent of individuals in 
our sample have IRA wealth equal to at least two years of average Social Security benefits, in line with our estimates from the tax data. If we use total wealth, the fraction is much larger: around 64 percent of the sample has wealth equal to at least two years of average Social Security benefits. The vast majority of people - around 72 percent - claim Social Security before full retirement age. According to the last column of Table 2, that fraction is slightly higher (73 percent) among those in the low total wealth category. Using just IRA assets, approximately 26 percent of the sample has wealth equal to at least four times the average Social Security benefit; this fraction increases to 54 percent when total wealth is used instead of IRA assets (see Table 1). Individuals in the low total wealth category are slightly more likely (again around 73 percent) to claim early (see Table 2). If we limit our sample to those born in 1938 or later, who receive more generous delayed retirement credits from delaying Social Security benefits, the difference in claiming behavior by wealth is somewhat more pronounced. In particular, the second column of Table 2 shows that around 80 percent of those in the low total wealth category claim early, versus 74 percent in the high wealth category.

Table 3 shows the results from our regression analysis. Each column represents a different observable characteristic, and the mean of the outcome variable is shown at the bottom of the table. Since the first five outcome variables are binary, we use a logit specification and report marginal effects in the table. For the last three outcome variables, we report coefficients from OLS regressions. The coefficients of interest are the ones on whether the individual claimed Social Security prior to his or her full retirement age. We find that claiming prior to the full retirement age is associated with a 3.33 percentage point (3.95 percent relative to the dependent variable mean of 84.3 percent) reduction in the probability of being in good or excellent health, and 2.07 percentage point (3.03 percent relative to the dependent variable mean) 
reduction in the subjective probability of living to 75 . While these relationships are statistically significant, they are quite small in magnitude. ${ }^{19}$ Also, there is no evidence that spousal health, long-term care insurance coverage, or expectations of changes in Social Security benefits are correlated with claiming prior to the full retirement age. Our subjective mortality results are consistent with previous papers examining the connection between subjective morality and claiming ages in the HRS (Hurd, Smith, and Zissimopoulos; Glickman and Hermes 2015).

In the tax data, we do not observe many other characteristics of individuals other than what is available from tax reporting. However, we can examine mortality by claim age to test whether the relationship between subjective mortality expectations and claim age translate into differences between realized mortality and claim age. The mortality hazards by Social Security claiming age are shown in Figure 4. The figure shows that mortality hazards decrease as claim age increases, suggesting that one reason people may claim Social Security benefits early is due to private information regarding their health status. In particular, delaying benefits to older ages has lower returns for those with higher than average mortality, and these individuals are also more likely to stop work early. We calculate the 5-year mortality rate between 66 and 71 for all three groups. The group that claims Social Security prior to 2005 has a 5-year mortality rate of 8.2 percent. The group that claims in 2005 has a 6.3 percent chance of dying prior to 2011, while those who claim after 2005 have only a 4.6 percent chance of dying over the same 5-year period. ${ }^{20}$ We repeat this exercise separating the sample by wealth at age 62 , and find that the differences persist within similar wealth categories. ${ }^{21}$ These results suggest that the relationship

\footnotetext{
${ }^{19}$ We also try dividing early claimers into two groups: those who claimed at age 62 and those who claimed after age 62 but before the full retirement age. We find that the coefficients for these two groups are similar in magnitude. These results are not reported but are available upon request.

${ }^{20}$ We again try dividing early claimers into two groups: those who claimed in 2002 and those who claimed in 2003 or 2004. Both of these groups have similar mortality; the former group has an 8.4 percent 5 -year mortality rate and the latter a 7.9 percent 5-year mortality rate.

${ }^{21}$ These results are not reported but are available upon request.
} 
between subjective mortality and claiming age found in the HRS translates into a relationship between actual mortality rates and claiming age for the 1940 birth cohort. They are also consistent with prior research on actual morality and claiming (Waldron 2002; Beauchamp and Wagner 2012).

\section{Conclusion}

In this paper, we explore the relationship between when people claim Social Security benefits relative to when they take distributions from their IRAs, and how IRA wealth compares to Social Security benefits. Our analysis shows that a significant share of individuals in our sample has sufficient IRA wealth to finance a delay in claiming Social Security benefits. Recent literature suggests that the financial gains to delaying Social Security benefits are large, even for individuals with higher than average mortality rates (Shoven and Slavov 2014). We also explore other characteristics of those who claim prior to the full retirement age using both administrative tax data as well as supplemental data from the HRS. We find that those who claim prior to the full retirement age have worse self-reported health status, higher subjective mortality probabilities, and higher realized mortality. These findings are consistent with both the idea that delayed claiming provides less financial gain to those who have higher than average mortality, and the possibility that those who claim prior to the full retirement age are those with worklimiting disabilities who leave the labor force earlier and claim Social Security once they are no longer working.

We express caution when interpreting these results. On one hand, the fraction of individuals who have IRA assets to finance a delay in claiming Social Security benefits is a significant underestimate given that IRAs represent only one source of assets. On the other 
hand, for many with financial assets, using them to delay Social Security claiming is unlikely to be optimal given precautionary savings and bequest motives.

In addition, the statistics we report are relevant for our selected sample, namely the subset of the 1940 birth cohort that is likely to be making a decision of when to claim Social Security retired worker benefits. This sample excludes married women (who are more likely to be secondary earners and receiving spousal benefits) and those already receiving Social Security benefits prior to age 62 due to either disability or as widows. We choose this particular birth cohort because we are able to observe them from the year they turn 59 through the year they turn 71, spanning the time period during which individuals are permitted to take distributions from their tax-deferred retirement accounts without penalty. However, other cohorts may have different characteristics due to, for instance, a greater number of secondary earners who are making independent claiming decisions and different levels of stock market returns during their claiming years. Overall, our results suggest that decisions of when to claim Social Security are strongly associated with life expectancy, and that a significant share of the population can potentially finance a delay in Social Security claiming by accessing financial wealth earmarked for retirement. 


\section{References}

Annual Statistical Supplement, 2014. (2014). Retrieved from

http://www.ssa.gov/policy/docs/statcomps/supplement/2014/6a.html\#table6.a4

Beauchamp, Andrew and Mathis Wagner. 2012. "Dying to Retire: Adverse Selection and Welfare in Social Security." Unpublished manuscript.

Behaghel, Luc, and David Blau. 2012. "Framing Social Security Reform: Behavioral Responses to Changes in the Full Retirement Age." American Economic Journal: Economic Policy 4(4): 41-67.

Chai, Jingjing, Raimond Maurer, Olivia Mitchell, and Ralph Rogalla. 2013. "Exchanging Delayed Social Security Benefits for Lump Sums: Could This Incentivize Longer Work Careers?" Cambridge: National Bureau of Economic Research Working Paper no. 19032.

Di Nardi, Mariacristina, Eric French, and John B. Jones. 2010. "Why Do the Elderly Save? The Role of Medical Expenses. Journal of Political Economy 118(1): 39-75.

Fitzpatrick, Maria. 2015. "How Much Are Public School Teachers Willing to Pay for Their Retirement Benefits?” American Economic Journal: Economic Policy, forthcoming.

Glickman, Mark M. and Sharon Hermes. 2015. "Why Retirees Claim Social Security at 62 and How It Affects Their Retirement Income: Evidence from the Health and Retirement Study." The Journal of Retirement 2(3): 25-39.

Gustman, Alan L., Thomas L. Steinmeier, and Nahid Tabatabai. 2014. Updated Pension Wealth Data Files in the HRS Panel: 1992 to 2010 Part III. Health and Retirement Study researcher contributed dataset.

Hurd, Michael D. 1990. "Research on the Elderly: Economic Status, Retirement, and Consumption and Saving." Journal of Economic Literature 28(2): 565-637.

Hurd, Michael D. and Kathleen McGarry. 2002. "The Predictive Validity of Subjective Probabilities of Survival.” The Economic Journal 112(482): 966-985.

Hurd, Michael D., James P. Smith and Julie M. Zissimopoulos. 2004. "The Effects of Subjective Survival on Retirement and Social Security Claiming." Journal of Applied Econometrics 19(6): 761-775.

Munnell, Alicia and Anqi Chen. 2015. "Trends in Social Security Claiming." Center for Retirement Research at Boston College Issue Brief no. 15-8.

RAND HRS Data Files (2014). Retrieved from http://www.rand.org/labor/aging/dataprod/hrsdata.html 
Sass, Steve, Wei Sun, and Anthony Webb. 2013. "Social Security Claiming Decision of Married Men and Widow Poverty." Economics Letters 119(1): 20-23.

Shoven, John, and Sita Slavov. 2014a. "Does It Pay to Delay Social Security?" Journal of Pension Economics and Finance 13(2): 121-144.

Shoven, John, and Sita Slavov. 2014b. "Recent Changes in the Gains from Delaying Social Security." Journal of Financial Planning 27(3): 32-41.

Sun, Wei, and Anthony Webb. 2009. "How Much Do Households Really Lose by Claiming Social Security at Age 62?" Center for Retirement Research. Boston: Boston College.

Waldron, Hilary. 2002. "Do Early Retirees Die Early? Evidence from Three Independent Data Sets." Washington DC: Social Security Administration Office of Research, Evaluation, and Statistics Working Paper no. 97. 


\section{Figure 1}

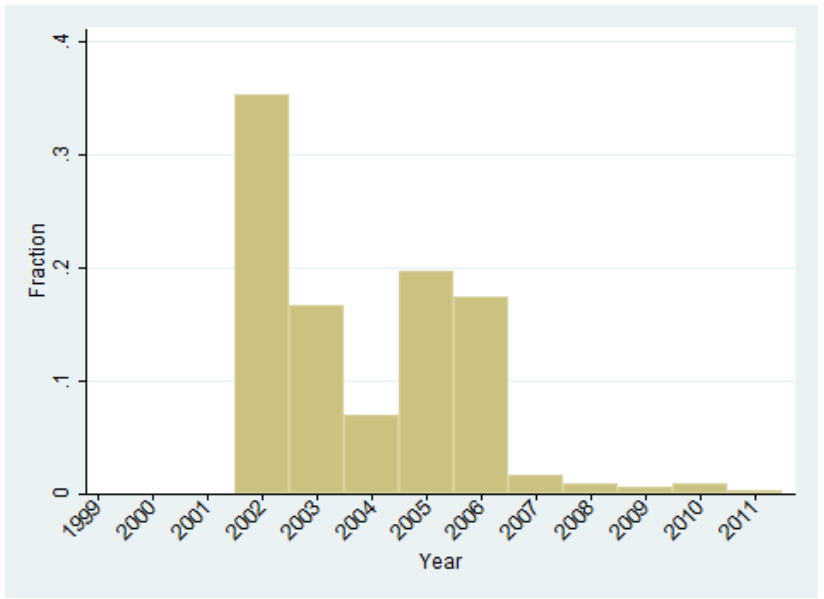

(a) First year of Social Security claim

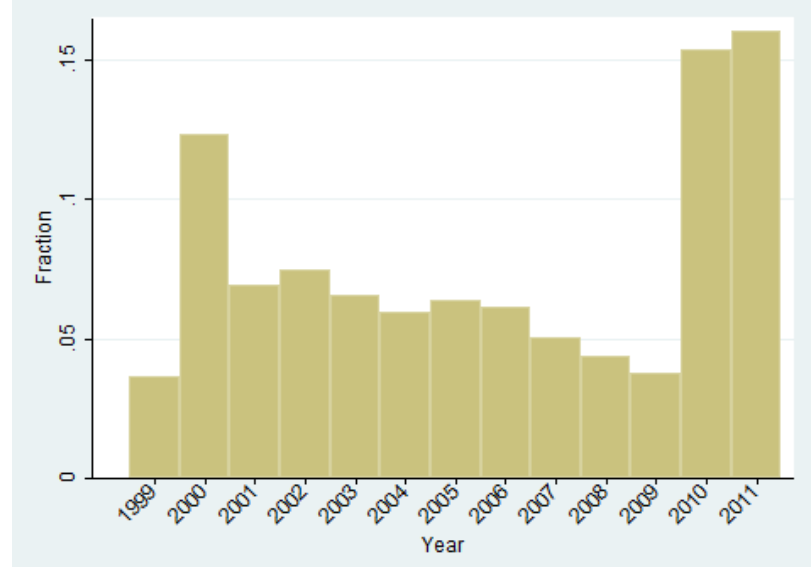

(b) First year of distribution from Traditional IRA

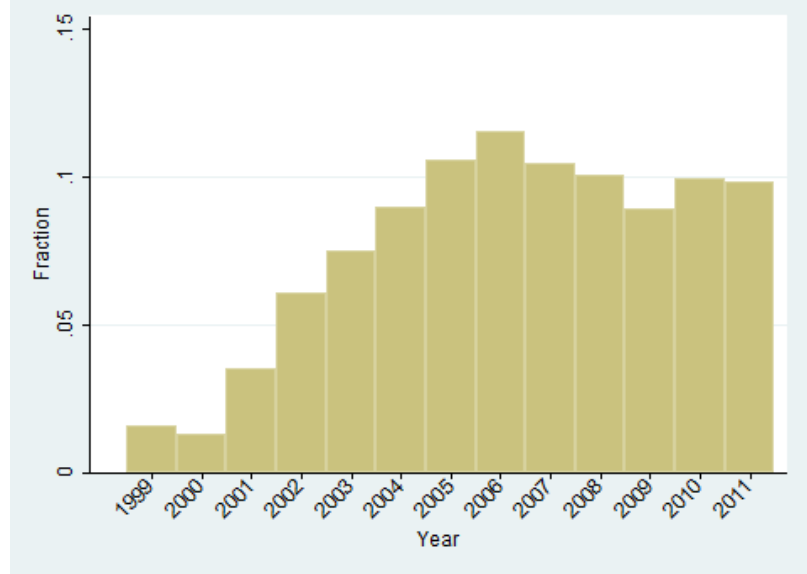

(c) First year of distribution from Roth IRA 
Figure 2

Difference between Social Security Claim Year and First Year of IRA Distribution

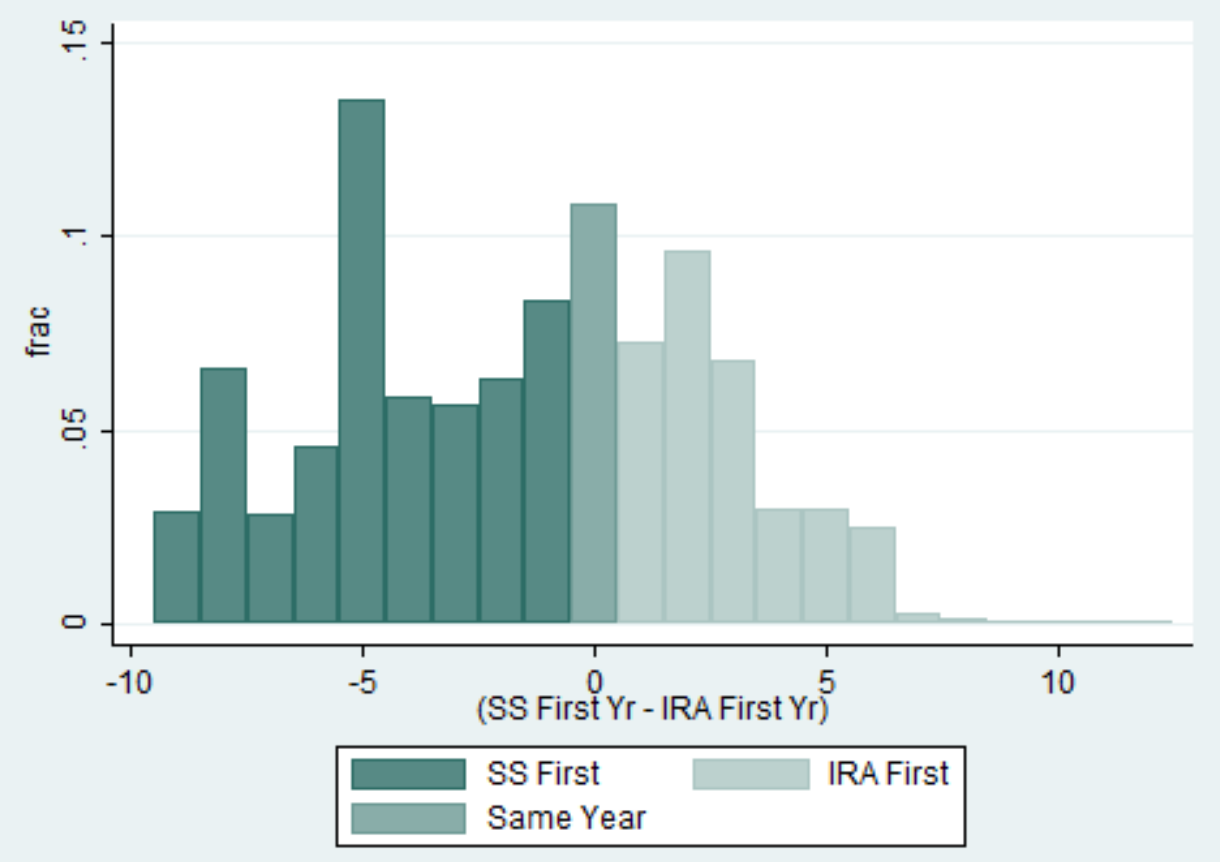




\section{Figure 3}

Percent of Households with IRA Fair Market Value Greater than Two or Four Years of Social Security Benefits

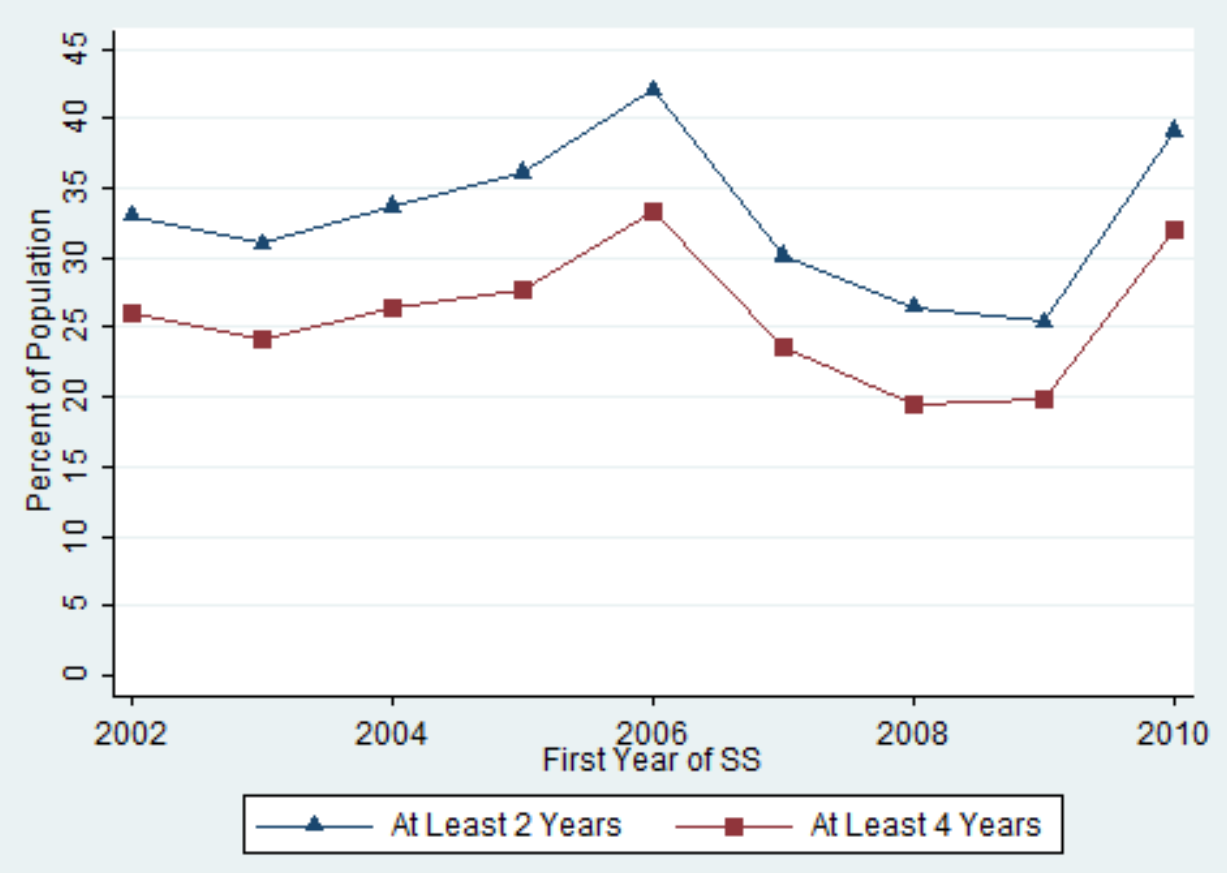




\section{Figure 4}

\section{Mortality Hazards by Social Security Claim Age}

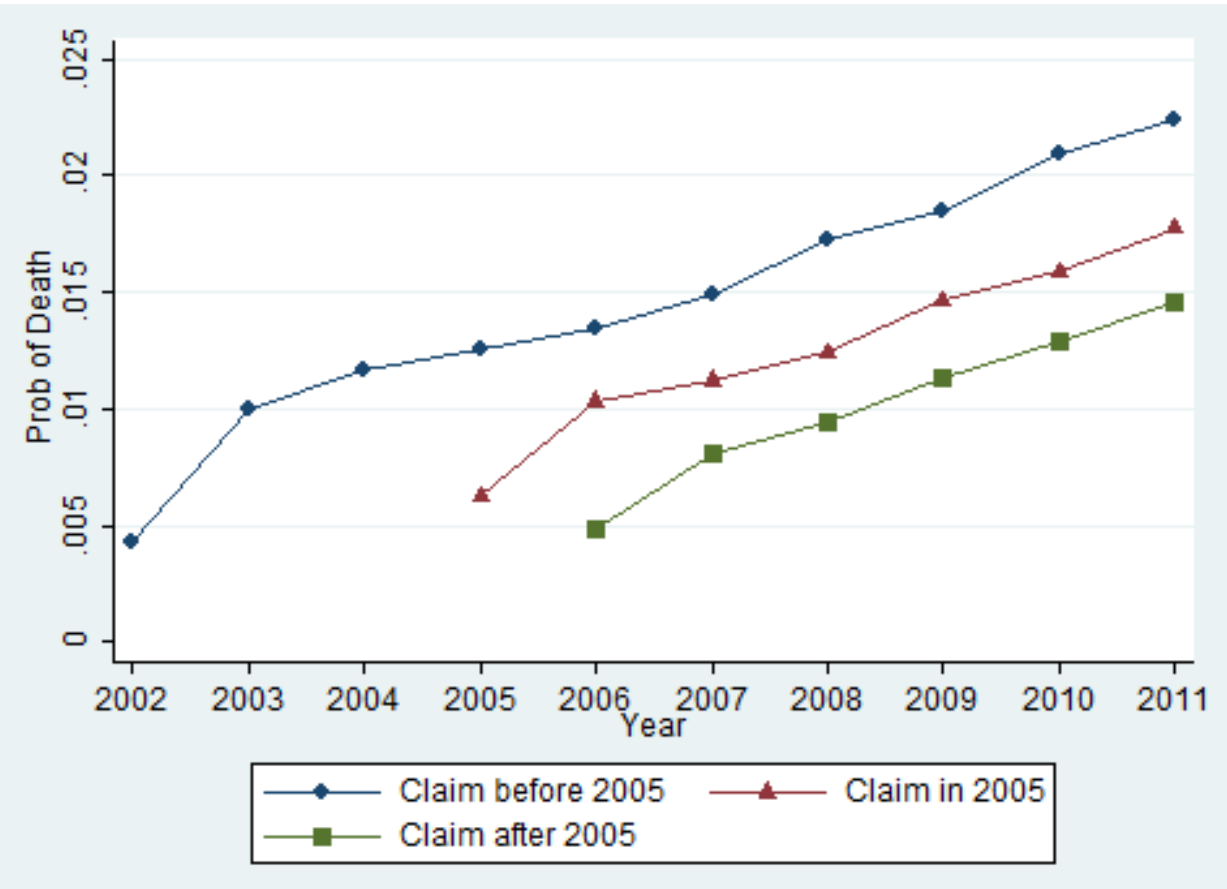


Table 1: Summary Statistics for HRS Sample

\begin{tabular}{lrrrrr}
\hline Variable & Obs & Mean & Std. Dev. & Min & Max \\
\hline Good health & 4359 & 0.84 & 0.36 & 0 & 1 \\
Spouse in good health & 2871 & 0.83 & 0.38 & 0 & 1 \\
Has long term care insurance & 4282 & 0.09 & 0.28 & 0 & 1 \\
Sposue has long term care insurance & 2802 & 0.08 & 0.28 & 0 & 1 \\
Financial planning horizon $\geq 5$ years & 4213 & 0.35 & 0.48 & 0 & 1 \\
P(Cut Social Security) & 3683 & 61.57 & 24.07 & 0 & 100 \\
P(Cut own Social Security) & 3535 & 43.51 & 26.85 & 0 & 100 \\
P(Live to 75) & 4213 & 68.18 & 23.96 & 0 & 100 \\
Claim before NRA & 4362 & 0.72 & 0.45 & 0 & 1 \\
Wealth & 4362 & 246641.90 & 1590488.00 & -1000000 & $9.02 \mathrm{E}+07$ \\
PIA for gender/cohort & 4362 & 11630.91 & 3148.26 & 6187.64 & 29016.12 \\
Wealth $>$ 2 x SS benefit for gender/cohort & 4362 & 0.64 & 0.48 & 0 & 1 \\
Wealth $>$ 4 x SS benefit for gender/cohort & 4362 & 0.54 & 0.50 & 0 & 1 \\
IRA balance $>$ 2x SS benefit for gender/cohort & 4362 & 0.35 & 0.48 & 0 & 1 \\
IRA balance $>$ 4x SS benefit for gender/cohort & 4362 & 0.26 & 0.44 & 0 & 1 \\
Birth year & 4362 & 1936.68 & 4.48 & 1928 & 1947 \\
Born in 1938 or later & 4362 & 0.43 & 0.50 & 0 & 1 \\
Less than high school & 4362 & 0.19 & 0.39 & 0 & 1 \\
GED & 4362 & 0.05 & 0.22 & 0 & 1 \\
High shool graduate & 4362 & 0.29 & 0.45 & 0 & 1 \\
Some college & 4362 & 0.21 & 0.41 & 0 & 1 \\
College+ & 4362 & 0.26 & 0.44 & 0 & 1 \\
White non-Hispanic & 4362 & 0.76 & 0.42 & 0 & 1 \\
Black non-Hispanic & 4362 & 0.14 & 0.35 & 0 & 1 \\
Hispanic & 4362 & 0.08 & 0.26 & 0 & 1 \\
Other race & 4362 & 0.02 & 0.14 & 0 & 1 \\
Female & 4362 & 0.21 & 0.40 & 0 & 1 \\
Married & 4362 & 0.67 & 0.47 & 0 & 1 \\
\hline Not Based on 4362 obs & &
\end{tabular}

Notes: Based on 4362 observations. Sample construction is described in Section 2. 
Table 2: Percent Claiming Early by Wealth and Birth Cohort

\begin{tabular}{lccc}
\hline & Born before 1938 & Born in 1938 or later & Full Sample \\
\hline Wealth $\leq 2$ years of benefits & $68.2 \%$ & $80.4 \%$ & $73.3 \%$ \\
Wealth $>2$ years of benefits & $69.1 \%$ & $74.4 \%$ & $71.4 \%$ \\
\hline IRA $\leq 2$ years of benefits & $67.2 \%$ & $76.9 \%$ & $71.5 \%$ \\
IRA $>2$ years of benefits & $71.5 \%$ & $75.7 \%$ & $73.2 \%$ \\
\hline Wealth $\leq 4$ years of benefits & $67.2 \%$ & $80.0 \%$ & $72.7 \%$ \\
Wealth $>4$ years of benefits & $70.1 \%$ & $73.6 \%$ & $71.7 \%$ \\
\hline IRA $\leq 4$ years of benefits & $67.3 \%$ & $75.9 \%$ & $71.0 \%$ \\
IRA $>4$ years of benefits & $73.0 \%$ & $78.2 \%$ & $75.2 \%$ \\
\hline
\end{tabular}

Notes: Sample size is 4,362. Sample construction described in Section 2. 
Table 3: Relationship between early claiming and individual characteristics

\begin{tabular}{|c|c|c|c|c|c|c|c|c|}
\hline VARIABLES & $\begin{array}{c}\text { Good } \\
\text { Health } \\
\end{array}$ & $\begin{array}{c}(2) \\
\text { Spouse } \\
\text { Good } \\
\text { Health } \\
\end{array}$ & $\begin{array}{c}\text { (3) } \\
\text { Has Long } \\
\text { Term Care } \\
\text { Insurance }\end{array}$ & $\begin{array}{c}(4) \\
\text { Spouse Has } \\
\text { Long Term } \\
\text { Care } \\
\text { Insurance } \\
\end{array}$ & $\begin{array}{c}(5) \\
\text { Financial } \\
\text { Planning } \\
\text { Horizon } \geq 5 \\
\text { years } \\
\end{array}$ & $\begin{array}{l}\text { P(Cut Social } \\
\text { Security) }\end{array}$ & $\begin{array}{c}\mathrm{P}(\text { Cut Own } \\
\text { Social } \\
\text { Security }) \\
\end{array}$ & $\mathrm{P}($ Live to 75$)$ \\
\hline Claim before NRA & $\begin{array}{c}-0.0333 * * * \\
(0.0120)\end{array}$ & $\begin{array}{c}-0.00480 \\
(0.0157)\end{array}$ & $\begin{array}{c}0.00631 \\
(0.00932)\end{array}$ & $\begin{array}{l}0.00214 \\
(0.0119)\end{array}$ & $\begin{array}{l}-0.0112 \\
(0.0162)\end{array}$ & $\begin{array}{l}0.0142 \\
(0.891)\end{array}$ & $\begin{array}{l}-0.104 \\
(1.058)\end{array}$ & $\begin{array}{c}-2.068 * * \\
(0.817)\end{array}$ \\
\hline Wealth/SS benefit in second quartile & $\begin{array}{c}0.0395^{* *} \\
(0.0161)\end{array}$ & $\begin{array}{c}0.0969^{* * *} \\
(0.0179)\end{array}$ & $\begin{array}{l}0.0240^{* *} \\
(0.0108)\end{array}$ & $\begin{array}{c}0.0352 * \\
(0.0203)\end{array}$ & $\begin{array}{c}0.0476 * * \\
(0.0205)\end{array}$ & $\begin{array}{l}-1.188 \\
(1.214)\end{array}$ & $\begin{array}{c}-2.760^{* *} \\
(1.345)\end{array}$ & $\begin{array}{c}2.463^{* *} \\
(1.131)\end{array}$ \\
\hline Wealth/SS benefitin third quartile & $\begin{array}{c}0.0875^{* * *} \\
(0.0166)\end{array}$ & $\begin{array}{c}0.129^{* * *} \\
(0.0193)\end{array}$ & $\begin{array}{c}0.0367 * * * \\
(0.0118)\end{array}$ & $\begin{array}{c}0.0602 * * * \\
(0.0196)\end{array}$ & $\begin{array}{c}0.122^{* * *} \\
(0.0216)\end{array}$ & $\begin{array}{c}1.234 \\
(1.204)\end{array}$ & $\begin{array}{l}-1.637 \\
(1.392)\end{array}$ & $\begin{array}{c}1.271 \\
(1.179)\end{array}$ \\
\hline Wealth/SS benefit in top quartile & $\begin{array}{c}0.110 * * * \\
(0.0172)\end{array}$ & $\begin{array}{c}0.134 * * * \\
(0.0215)\end{array}$ & $\begin{array}{c}0.0898^{* * *} \\
(0.0142)\end{array}$ & $\begin{array}{c}0.0889 * * * \\
(0.0193)\end{array}$ & $\begin{array}{c}0.186 * * * \\
(0.0233)\end{array}$ & $\begin{array}{c}1.842 \\
(1.277)\end{array}$ & $\begin{array}{l}-2.794^{*} \\
(1.468)\end{array}$ & $\begin{array}{l}2.854^{* *} \\
(1.192)\end{array}$ \\
\hline Born in 1938 or later & $\begin{array}{c}-0.00564 \\
(0.0110)\end{array}$ & $\begin{array}{c}-0.0258^{*} \\
(0.0137)\end{array}$ & $\begin{array}{c}0.0372^{* * *} \\
(0.00881)\end{array}$ & $\begin{array}{c}0.0520 * * * \\
(0.0107)\end{array}$ & $\begin{array}{c}0.000855 \\
(0.0147)\end{array}$ & $\begin{array}{c}4.221^{* * *} \\
(0.795)\end{array}$ & $\begin{array}{c}3.398^{* * *} \\
(0.914)\end{array}$ & $\begin{array}{c}0.159 \\
(0.741)\end{array}$ \\
\hline GED & $\begin{array}{c}0.0572 * \\
(0.0298)\end{array}$ & $\begin{array}{c}0.0355 \\
(0.0291)\end{array}$ & $\begin{array}{l}0.00906 \\
(0.0201)\end{array}$ & $\begin{array}{c}-0.0182 \\
(0.0287)\end{array}$ & $\begin{array}{l}-0.0126 \\
(0.0360)\end{array}$ & $\begin{array}{l}4.131^{*} \\
(2.132)\end{array}$ & $\begin{array}{l}-2.169 \\
(2.331)\end{array}$ & $\begin{array}{c}2.550 \\
(2.062)\end{array}$ \\
\hline High school & $\begin{array}{c}0.104 * * * \\
(0.0185)\end{array}$ & $\begin{array}{c}0.0549 * * * \\
(0.0183)\end{array}$ & $\begin{array}{c}0.0109 \\
(0.0120)\end{array}$ & $\begin{array}{l}-0.0200 \\
(0.0182)\end{array}$ & $\begin{array}{l}-0.0151 \\
(0.0231)\end{array}$ & $\begin{array}{c}3.386^{* * *} \\
(1.307)\end{array}$ & $\begin{array}{l}-2.715^{*} \\
(1.426)\end{array}$ & $\begin{array}{c}4.877 * * * \\
(1.249)\end{array}$ \\
\hline Some college & $\begin{array}{c}0.119 * * * \\
(0.0195)\end{array}$ & $\begin{array}{c}0.0713 * * * \\
(0.0207)\end{array}$ & $\begin{array}{c}0.0400^{* * *} \\
(0.0137)\end{array}$ & $\begin{array}{c}-0.00163 \\
(0.0184)\end{array}$ & $\begin{array}{c}-0.00286 \\
(0.0246)\end{array}$ & $\begin{array}{c}3.752^{* * *} \\
(1.391)\end{array}$ & $\begin{array}{c}-4.671 * * * \\
(1.533)\end{array}$ & $\begin{array}{c}6.799 * * * \\
(1.321)\end{array}$ \\
\hline College + & $\begin{array}{c}0.179 * * * \\
(0.0186)\end{array}$ & $\begin{array}{c}0.136^{* * *} \\
(0.0239)\end{array}$ & $\begin{array}{c}0.0752^{* * *} \\
(0.0148)\end{array}$ & $\begin{array}{l}0.00873 \\
(0.0180)\end{array}$ & $\begin{array}{c}0.0717^{* * *} \\
(0.0253)\end{array}$ & $\begin{array}{c}6.082 * * * \\
(1.410)\end{array}$ & $\begin{array}{c}-7.279^{* * *} \\
(1.567)\end{array}$ & $\begin{array}{c}8.538^{* * *} \\
(1.311)\end{array}$ \\
\hline Black - non-Hispanic & $\begin{array}{l}-0.0234 \\
(0.0155)\end{array}$ & $\begin{array}{l}-0.0356 \\
(0.0218)\end{array}$ & $\begin{array}{l}0.00897 \\
(0.0157)\end{array}$ & $\begin{array}{l}0.00413 \\
(0.0194)\end{array}$ & $\begin{array}{c}-0.0669 * * * \\
(0.0228)\end{array}$ & $\begin{array}{c}-6.653^{* * *} \\
(1.282)\end{array}$ & $\begin{array}{c}-2.870^{* *} \\
(1.460)\end{array}$ & $\begin{array}{c}6.732^{* * * *} \\
(1.173)\end{array}$ \\
\hline Hispanic & $\begin{array}{c}-0.0586^{* * *} \\
(0.0204)\end{array}$ & $\begin{array}{c}-0.0772 * * * \\
(0.0214)\end{array}$ & $\begin{array}{c}-0.0413^{* *} \\
(0.0169)\end{array}$ & $\begin{array}{c}-0.0530^{*} \\
(0.0312)\end{array}$ & $\begin{array}{c}-0.154 * * * \\
(0.0279)\end{array}$ & $\begin{array}{c}-8.141 * * * \\
(1.654)\end{array}$ & $\begin{array}{l}-1.263 \\
(1.727)\end{array}$ & $\begin{array}{l}-1.210 \\
(1.600)\end{array}$ \\
\hline Other Race - non-Hispanic & $\begin{array}{l}-0.0150 \\
(0.0401)\end{array}$ & $\begin{array}{c}0.0279 \\
(0.0518)\end{array}$ & $\begin{array}{c}-0.0465^{* *} \\
(0.0205)\end{array}$ & $\begin{array}{l}-0.0731 \\
(0.0564)\end{array}$ & $\begin{array}{l}-0.0511 \\
(0.0512)\end{array}$ & $\begin{array}{l}-4.711^{*} \\
(2.818)\end{array}$ & $\begin{array}{c}4.602 \\
(3.662)\end{array}$ & $\begin{array}{l}-1.823 \\
(2.617)\end{array}$ \\
\hline Female & $\begin{array}{l}-0.0134 \\
(0.0187)\end{array}$ & & $\begin{array}{l}0.00713 \\
(0.0157)\end{array}$ & & $\begin{array}{l}-0.0401 \\
(0.0257)\end{array}$ & $\begin{array}{l}-1.224 \\
(1.422)\end{array}$ & $\begin{array}{c}3.108^{*} \\
(1.589)\end{array}$ & $\begin{array}{c}4.113 * * * \\
(1.318)\end{array}$ \\
\hline Married & $\begin{array}{c}0.0131 \\
(0.0164)\end{array}$ & & $\begin{array}{c}-0.0161 \\
(0.0140)\end{array}$ & & $\begin{array}{c}0.0181 \\
(0.0226)\end{array}$ & $\begin{array}{c}0.447 \\
(1.248)\end{array}$ & $\begin{array}{c}1.344 \\
(1.428)\end{array}$ & $\begin{array}{c}0.920 \\
(1.153)\end{array}$ \\
\hline Dependent variable mean & 0.843 & 0.830 & 0.088 & 0.085 & 0.352 & 61.572 & 43.507 & 68.184 \\
\hline $\begin{array}{l}\text { Observations } \\
\text { R-squared }\end{array}$ & 4,359 & 2,871 & 4,282 & 2,802 & 4,213 & $\begin{array}{l}3,683 \\
0.046\end{array}$ & $\begin{array}{l}3,535 \\
0.017\end{array}$ & $\begin{array}{l}4,213 \\
0.035\end{array}$ \\
\hline
\end{tabular}

Notes: Coefficients reported in columns (1)-(5) are marginal effects from logit regressions. Columns (6)-(8) are coefficients from OLS regressions in which the dependent variable ranges from 0 (no chance) to 100 (certainty). Constant terms not reported. Standard erros clustered by household in parentheses.

$* * * \mathrm{p}<0.01,{ }^{* *} \mathrm{p}<0.05,{ }^{*} \mathrm{p}<0.1$ 